\title{
CHARACTERISTICS OF HYDROXYPROPYL STARCH OF SORGHUM MUTANT LINE ZH-30 AND ITS POTENTIAL USE IN PAPER INDUSTRY
}

\author{
Soeranto Human \\ Center for the Application of Isotope and Radiation Technology, \\ National Nuclear Energy Agency (BATAN) \\ Jl. Cinere Pasar Jumat, Jakarta, Indonesia \\ Dwi Djoko Slamet Santosa \\ PT. Multi Makmur Utama, Jakarta
}

\begin{abstract}
CHARACTERISTICS OF HYDROXYPROPYL STARCH OF SORGHUM MUTANT LINE ZH-30 AND ITS POTENTIAL USE IN PAPER INDUSTRY. Sorghum mutant line Zh-30 is a breeding line developed at the Center for the Application of Isotope and Radiation Technology, BATAN by using mutation techniques. Gamma irradiation with the dose of 300 Gy was used to induced plant genetic variability. Through selection processes in several generations, the mutant line $\mathrm{Zh}-30$ was identified to have better agronomic characteristics, better grain quality and higher yield than the original variety. Research on starch quality of this mutant line was done to identify its potential use in a paper industry. Hydroxypropyl starch derivatives of this sorghum lines were prepared by varying alkalinity of the reaction mixtures using propylene oxide to reach Molar of Substitution (MS) of 0-0.180. Its pasting behavior, paste properties and application in wet end paper processing were evaluated. The optimal amount of addition of hydroxypropyl starch was 1-2 \%. At this level, drainage time was lower, so that it decreased paper machine speed. At higher level, it did not improve the burst and tensile strengths but tended to decrease the tear strength of handsheets. The properties of lower pasting temperature, higher water holding capacity lower retrogradation susceptibility, increased viscosity and stability of pastes suggested that hydroxypropyl starch of sorghum ZH-30 was suitable for use in wet end paper processing. Comparing to the original starch, the hydroxypropyl starch of sorghum Zh-30 could significantly improve the strength of handsheets.
\end{abstract}

Keywords: Sorghum mutant line, hydroxypropyl starch, papermaking.

\section{INTRODUCTION}

Sorghum is used not only for human food and animal feed, but its starch can also be used for raw materials for different kinds of industry such as bioethanol, bear, wine, syrup, glue, degradable plastics and paper industries [1]. Sorghum grain contains about $75 \%$ carbohydrate which can be converted and modified to become hydroxypropyl starch. This modified starch derivatives are the most common type of dry strength additive used in the paper industry [2]. Hydroxypropyl starch is prepared by the reaction between starch and propylene oxide in the presence of aqueous alkali needed for good reaction efficiency, and sodium sulfate to repress the swelling tendency. In paper industry, hydroxypropyl starch are used to lower the gelatinization temperature, to decrease the retrogradation and gelling 
tendencies of amylose containing starches, and to increase the water holding capacity of starch dispersion under low temperature condition of storage.

Starch granule is not structurally homogeneous from physical and chemical point of view. Amylose, the main component of the crystalline region, is more tightly packed. Amylopectin, the branched portion, is packed in amorphous region which is the most readily penetrable by water and low molecular weight water soluble solutes. Dry strength is an inherent structural property of a paper sheet which is due primarily to the development of fibre to fibre bonds during consolidation and drying of the fibre weaves [3]. The retention of hydroxypropyl starch on the fibres is affected by the charge density. The decrease in adsorption at a high MS is due to the charge reversal of the cellulose surface with a subsequent repulsion between the cellulose surface and hydroxypropyl starch added [3].

The Center for the Application of Isotope and Radiation Technology, BATAN has developed some mutant lines of sorghum through induced mutation techniques by using gamma irradiation. One of the promising lines, Zh-30, which was developed from Zhengzu variety originated from China. Through selection processes in several generations, this mutant line was identified to have better agronomic characteristics, better grain quality and higher yield capability than the original variety Zhengzu in dry seasons. In this research, Zh-30 was analyzed for its starch quality for wet end paper processing industry purposes.

The present study investigates the highest alkalinity of reaction mixture and highest proportion of propylene oxide feasible for derivatization of sorghum Zh-30 starch. The objective is to study the effects of propylene oxide levels during hydroxypropylation and the impact of changed molar substitution on the properties and application of sorghum Zh-30 modified starch in the wet end paper processing.

\section{MATERIALS AND METHODS}

\section{Materials}

Sorghum grain of $\mathrm{Zh}-30$ mutant line was provided by the Center of Application of Isotope and Radiation Technology, BATAN, Jakarta. Original and hydroxypropyl starch of sorghum Zh-30 were prepared by PT. Multi Makmur Utama. Bamboo pulp materials were kindly supplied by PT. Pintu Mas Mulia Kimia, Jakarta.

Equipments used for making and measuring handsheets (paper samples) were available at pulp and paper unit of the Indonesian Center for Agricultural Postharvest Research and Development in Bogor. These equipments included valley beater, disintegrator, sheet machine, bursting tester, tearing tester, etc. 


\section{Methods}

Preparation of Hydroxypropyl Starch of Sorghum Zh-30

Hydroxypropyl starches were prepared from sample of sorghum Zh-30 starch using Leegwater and Luten method as described by Ruttenberg et.al. [4]. The reagent mixtures used in this method are shown Table 1. Alkaline solution $(200 \mathrm{ml})$ was added to the jars at room temperature. The mixtures were heated to $40^{\circ} \mathrm{C}$ in a water bath, propylene was added, and kept in an orbital shaking water bath at $40^{\circ} \mathrm{C}$ for $24 \mathrm{hr}$, and then neutralized (adjusted $\mathrm{pH}$ around 7) by adding sulphuric acid or $\mathrm{BaCl}_{2}$. The starch suspensions were then centrifuged, vacuumed and dried.

Table 1. Reagent mixture used in derivatization of hydroxypropyl starch.

\begin{tabular}{|c|c|c|}
\hline Sample number & $\begin{array}{c}\mathrm{NaOH} \text { concentration (M) in } \\
0.86 \mathrm{M} \mathrm{Na}_{2} \mathrm{SO}_{4}{ }^{\mathrm{a}}\end{array}$ & Propylene oxide (ml) \\
\hline $0^{\mathrm{b}}$ & - & - \\
\hline 1 & 0.165 & 0.0 \\
\hline 2 & 0.165 & 3.5 \\
\hline 3 & 0.165 & 7.0 \\
\hline 4 & 0.165 & 10.5 \\
\hline 5 & 0.290 & 0.0 \\
\hline 6 & 0.290 & 3.5 \\
\hline 7 & 0.290 & 7.0 \\
\hline 8 & 0.290 & 10.5 \\
\hline 9 & 0.395 & 0.0 \\
\hline 10 & 0.395 & 3.5 \\
\hline 11 & 0.395 & 7.0 \\
\hline 12 & 0.395 & 10.5 \\
\hline
\end{tabular}

a $200 \mathrm{ml}$ of each solution was used per $80 \mathrm{~g}$ starch

${ }^{\mathrm{b}}$ untreated original starch

\section{Laboratory test}

Physical properties in term of color were evaluated. Color was analyzed on chromameter CR-300 (Minolta, Japan). Sample were spread on a stock of white paper and the lightress (L), color hue (a) and saturation (b) values were recorded. A white standard tile $(\mathrm{L}=100, \mathrm{a}=0$, and $\mathrm{b}=0)$ provided with the instrument was used to calibrate the chromameter. $\mathrm{pH}$ of the sample starch was determined electrometrically on a suspension of $40 \mathrm{~g}$ of dry solids in $100 \mathrm{ml}$ distilled water. Chemical compositions of the samples were analyzed according to the standard methods of AOAC [5].

The moisture content of original starch was analyzed by oven drying at $105^{\circ} \mathrm{C}$, the fiber was determined by acid digestion, protein by Kjeldahl 
procedure, lipid by exhaustive solvent extraction followed by evaporation to constant weight, and ash by dry combustion. Amylose was determined by iodine binding and subsequent spectrophotometric measurement at $590 \mathrm{~nm}$ as described by AOAC [5]. Molar Substitution (MS) was determined by ether cleavage, to release propylene glycol, followed by dehydration into propanal and allyl alcohol by sulphuric acid, and then reacted with ninhydrin to produce coloured complexes which were measured spectrophotometrically at $590 \mathrm{~nm}[5]$.

Pasting characteristic of starch samples were examined in a Brabender Amylograph using $75 \mathrm{rpm}$ and torque of $700 \mathrm{~cm}$.g equivalents to $1000 \mathrm{BU}$. The starch slurry $(10 \%)$ was pasted at a heating rate of $1.5^{\circ} \mathrm{C}$ from $30^{\circ} \mathrm{C}$ to $93^{\circ} \mathrm{C}$, held at $90^{\circ} \mathrm{C}$ for 20 minutes, cooled at $50^{\circ} \mathrm{C}$ for 20 minutes at the same rate and finally held at $50^{\circ} \mathrm{C}$ for 20 minutes. The following measurements were noted from the amylograph curve: gelatinization temperature $\left({ }^{\circ} \mathrm{C}\right)$, peak temperature $\left({ }^{\circ} \mathrm{C}\right)$, peak viscosity $(\mathrm{BU})$, viscosity at $93^{\circ} \mathrm{C}$, viscosity being held at $93^{\circ} \mathrm{C}$ for 20 minutes, viscosity at $50^{\circ} \mathrm{C}$ and viscosity being held at $50^{\circ} \mathrm{C}$ for 20 minutes.

The pulp handsheets were by conditioned and controlled at $65 \pm 2 \%$ $\mathrm{RH}$ and $27 \pm 1^{\circ} \mathrm{C}$ at least $24 \mathrm{hrs}$, before and during testing by following TAPPI T402. Moisture in Bamboo pulp and waste paper were measured by drying in $105^{\circ} \mathrm{C}$ for $4 \mathrm{hr}$. Forming handsheets followed TAPPI T205 by soaking small pieces of pulp $30 \mathrm{~g}$ (dry wt.) in water at least $4 \mathrm{hr}$, making volume to $2 \mathrm{l}$, disintegrating, forming handsheets and drying in ambient condition. The pulp evaluation was done by using PFI Mill. Drainage time (TAPPI T221) was measured and the stock temperature was adjusted at $20 \pm$ $5^{\circ} \mathrm{C}$. The other testing methods for testing pulp and handsheets such as freeness, grammage or weight per unit area, thickness or caliper, burst strength, tear strength and cobb test also followed TAPPI methods [6].

Scanning electron microscopy (SEM) was done. The original and hydroxypropyl sorghum Zh-30 starch sample were dehydrated with 95\% alcohol at room temperature for 10 minutes, stirred and then put them on a filter paper (no. 4) for 24 hours for dring. A half of dry samples was broken by hand and put 3 pieces on a SEM stub using double-side tape with carbon paint cement for long section at the base of each specimen. The specimens were then spattered with gold using sputter coater to obtain conductivity and observed under a scanning electron microscope (JSM-5600 LV, JEOL, Japan) operated at an accelerating voltage of $10 \mathrm{kV}$ at $\mathrm{x} 50$ and $\mathrm{x} 1.000$ magnification [7].

\section{RESULTS AND DISCUSSION}

The original starch gave color information as followed: $\mathrm{L}$ value (94.20), a value (-0.23), b value (3.90), $\mathrm{pH}$ (5.20), moisture (13.5\%), fiber $(0.12 \%)$, protein $(0.13 \%)$, lipid $(0.07 \%)$, ash $(0.25 \%)$ and amylose $(22.7 \%)$. 
MS values of starch derivatives was presented in Table 2. It can be seen from Table 2 that MS increased with higher levels of propylene oxide used and that series of sorghum $\mathrm{Zh}-30$ starch derivatives ranging in MS from 0-0.180 were obtained.

Slightly higher MS of the starch derived from preparation using 0.395 $\mathrm{M} \mathrm{NaOH}$ solution and $10.5 \mathrm{ml}$ of propylene oxide (sample no. 12, MS 0.180 ), as compared to those using solution containing $\mathrm{NaOH}$ of the same molarity and $7.0 \mathrm{ml}$ of propylene oxide (sample no. 11, MS 0.125) was observed. Probably, sample no. 12 had swollen to a little extent during preparation and produced viscous layers which reduced the reaction efficiency. Furthermore, some soluble portion containing high functional groups might loss during washing out the salt. Generally hydroxypropyl starch with MS higher than 0.1 was difficult to obtain because of decrease in the temperature of granule swelling.

Table 2. Molar Substitution (MS) of starch derivatives ${ }^{\mathrm{a}}$

\begin{tabular}{|c|c|}
\hline Sample number & Molar Substitution $^{(\mathbf{M S})}{ }^{\mathbf{b}}$ \\
\hline 0 & 0.000 \\
\hline 1 & 0.000 \\
\hline 2 & 0.018 \\
\hline 3 & 0.036 \\
\hline 4 & 0.048 \\
\hline 5 & 0.000 \\
\hline 6 & 0.020 \\
\hline 8 & 0.032 \\
\hline 9 & 0.066 \\
\hline 10 & 0.000 \\
\hline 11 & 0.090 \\
\hline 12 & 0.125 \\
\hline
\end{tabular}

${ }^{\text {a }}$ The sample numbers used here are the same as those in Table 1

${ }^{\mathrm{b}}$ Moles of hydroxypropyl group per mole of anhidroglucose

The pasting behaviour of the starch derivatives was determined using Brabender amylograph. Some interesting points are shown in Table 3. Original starch of mutant lines $\mathrm{Zh}-30$ was included for comparison. Both the rates of consistency development and the shapes of pasting curve differed markedly, depending on the MS. Pasting temperature and maximum consistency temperature were negatively correlated to the MS. Modified starch granule were more easily penetrated by water than the original starch, therefore they were more susceptible to gelatinization, resulting in significant changes in the pasting properties as shown in Table 3.

The hydroxypropyl starch had pasting properties that differed somewhat from those of original sorghum $\mathrm{Zh}-30$ starch. The pasting temperature was $0.5^{\circ} \mathrm{C}$ lower and the maximum consistency temperature was $6^{\circ} \mathrm{C}$ lower. This difference might be ascribed to the structural changes of 
sorghum Zh-30 starch granules taking place under the alkaline and temperature conditions used. Though, the differences in alkalinity made no difference in neither the pasting temperature of control starch nor the viscosity at $93^{\circ} \mathrm{C}$. Apart from MS, alkaline conditions used during the derivative preparation also exhibited no effect on pasting properties of the hydroxypropyl sorghum Zh-30 starches.

Table 3. Pasting behaviour of hydroxypropyl starch of sorghum Zh-30.

\begin{tabular}{|c|c|c|c|c|c|c|}
\hline MS & \multirow{2}{*}{$\begin{array}{c}\text { Peak } \\
\end{array}$} & Peak & \multicolumn{4}{|c|}{ Viscosity at (BU) } \\
\cline { 4 - 7 } & $\begin{array}{c}\text { Temperature } \\
\left({ }^{\circ} \mathrm{C}\right)\end{array}$ & $\begin{array}{c}\text { Viscosity } \\
(\mathrm{BU})\end{array}$ & $93^{\circ} \mathrm{C}$ & $93^{\circ} \mathrm{C} / 20$ & $50^{\circ} \mathrm{C}$ & $50^{\circ} \mathrm{C} / 20$ \\
\hline Control & 87.0 & 450 & 390 & 310 & 360 & 380 \\
\hline 0.000 & 84.5 & 360 & 320 & 360 & 380 & 410 \\
\hline 0.018 & 73.5 & 980 & 895 & 220 & 460 & 550 \\
\hline 0.036 & 68.5 & 920 & 830 & 260 & 480 & 510 \\
\hline 0.048 & 65.5 & 970 & 895 & 260 & 580 & 610 \\
\hline 0.000 & 81.0 & 340 & 320 & 350 & 380 & 440 \\
\hline 0.020 & 71.5 & 1040 & 845 & 280 & 520 & 560 \\
\hline 0.032 & 66.5 & 1080 & 820 & 260 & 550 & 610 \\
\hline 0.066 & 63.5 & 1020 & 855 & 210 & 560 & 580 \\
\hline 0.000 & 81.0 & 360 & 320 & 380 & 410 & 440 \\
\hline 0.090 & 62.2 & 1025 & 810 & 250 & 480 & 510 \\
\hline 0.125 & 64.5 & 1105 & 840 & 280 & 610 & 640 \\
\hline 0.180 & 65.0 & 1260 & 810 & 250 & 480 & 490 \\
\hline
\end{tabular}

In order to determine the amount of starch to be added for handsheets, the experiment was done. The results are shown in the Table 4 and Figure 1 (a).

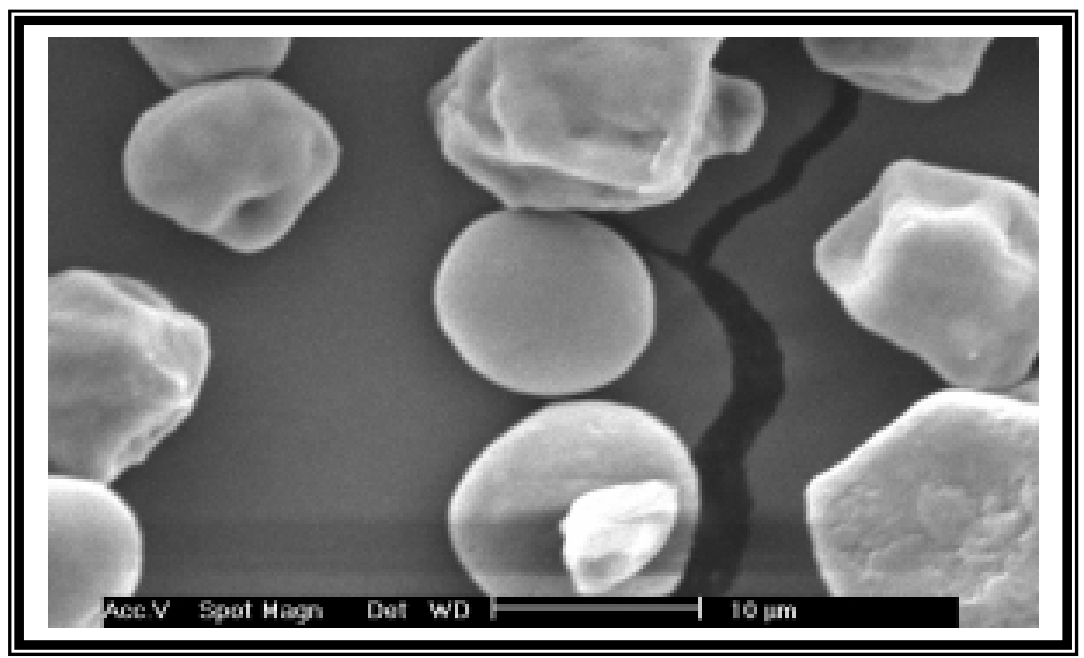

(a) 


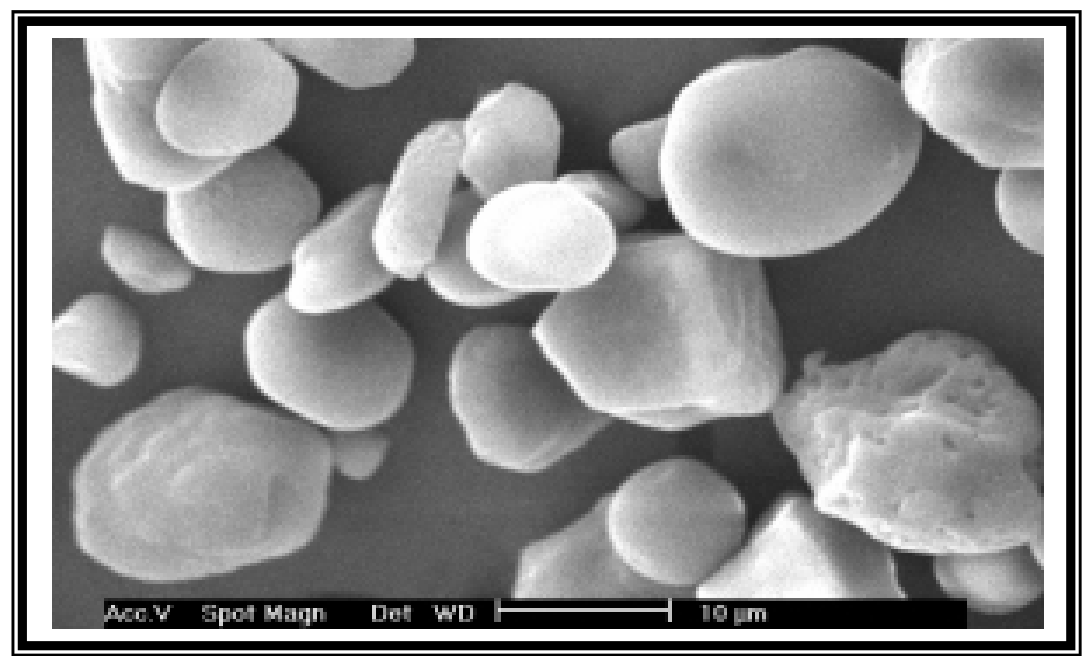

(b)

Figure 1. SEM of Sorghum Zh-30 starch: (a) Native sorghum starch; (b) Hydroxypropyl sorghum starch (MS 0.090).

Table 4. Physical property of handsheet filled with different percentage of original starch.

\begin{tabular}{|c|c|c|c|c|c|c|c|c|}
\hline $\begin{array}{c}\text { Percent } \\
\text { of } \\
\text { starch }\end{array}$ & $\begin{array}{c}\text { Gram. } \\
\left(\mathrm{g} / \mathrm{m}^{2}\right)\end{array}$ & $\begin{array}{c}\text { Thick. } \\
(\mu \mathrm{m})\end{array}$ & $\begin{array}{c}\text { AD } \\
(\mathrm{sec})\end{array}$ & $\begin{array}{c}\text { Porosity } \\
(\text { Guarley } \\
\text { second) }\end{array}$ & $\begin{array}{c}\text { DT } \\
(\mathrm{sec})\end{array}$ & $\begin{array}{c}\text { Tensile } \\
\text { Index } \\
(\mathrm{kN} . \mathrm{m} / \mathrm{kg})\end{array}$ & $\begin{array}{c}\text { Tear } \\
\text { Index } \\
(\mathrm{N} . \mathrm{m} / \mathrm{g})\end{array}$ & $\begin{array}{c}\text { Burst } \\
\text { Index } \\
(\mathrm{kPa} . \mathrm{m} / \mathrm{g})\end{array}$ \\
\hline 0 & 53.4 & 77.5 & 632 & 34.5 & 6.16 & 48.9 & 7.41 & 2.61 \\
\hline 2 & 55.2 & 83.7 & 593 & 33.9 & 6.81 & 51.7 & 7.35 & 2.95 \\
\hline 4 & 56.9 & 79.9 & 644 & 39.3 & 6.94 & 54.8 & 6.61 & 3.23 \\
\hline 6 & 57.7 & 81.5 & 648 & 39.4 & 7.79 & 57.1 & 6.34 & 3.24 \\
\hline 8 & 59.7 & 85.9 & 635 & 34.1 & 8.90 & 56.0 & 6.67 & 3.16 \\
\hline Note : & $\begin{array}{l}\text { AD } \\
\text { DT - Apparent Density } \\
\text { Gram - Drainage Time }\end{array}$ \\
\end{tabular}

As shown in Table 4, drainage time increased with the increasing amount of starch addition. This is not satisfactory for papermaking due to longer time required for processing. Apparent density at any percent of starch are almost equal, on the other hand, porosity does not follow any tried. When porosity is increased, it means air penetrate through the handsheet is difficult or handsheet has less pores. This may implies that native starch can be efficiently retained on the paper. Burst index with $4 \%$ starch addition is increased by $17.7 \%$ compared with control ( $0 \%$ starch addition). The order indices did not much increased when native starch amount was increased. So that native starch should be added at 2-4\% for saving starch cost and reducing the excess starch in the effluent, when native starch is in excess. 
Table 5. Physical properties of handsheets filled with hydroxypropyl starch, Molar of Substitution 0.090, in differet percentage.

\begin{tabular}{|c|c|c|c|c|c|c|c|c|}
\hline $\begin{array}{c}\text { Percent } \\
\text { of } \\
\text { starch }\end{array}$ & $\begin{array}{c}\text { Gram } \\
\left(\mathrm{g} / \mathrm{m}^{2}\right)\end{array}$ & $\begin{array}{c}\text { Thick. } \\
(\mu \mathrm{m})\end{array}$ & $\begin{array}{c}\mathrm{AD} \\
\left(\mathrm{kg} / \mathrm{m}^{3}\right)\end{array}$ & $\begin{array}{c}\text { Porosity } \\
(\text { Gurley } \\
\text { second })\end{array}$ & $\begin{array}{c}\text { DT } \\
(\mathrm{sec})\end{array}$ & $\begin{array}{c}\text { Tensile } \\
\text { Index } \\
(\mathrm{kN} . \mathrm{m} / \mathrm{kg})\end{array}$ & $\begin{array}{c}\text { Tear } \\
\text { Index } \\
(\mathrm{N} . \mathrm{m} / \mathrm{g})\end{array}$ & $\begin{array}{c}\text { Burst } \\
\text { Index } \\
(\mathrm{kPa} . \mathrm{m} / \mathrm{g})\end{array}$ \\
\hline 0 & 53.4 & 77.5 & 632 & 34.5 & 6.16 & 48.9 & 7.41 & 2.61 \\
\hline 1 & 58.7 & 85.9 & 624 & 23.1 & 6.33 & 53.8 & 6.98 & 2.93 \\
\hline 2 & 57.4 & 82.3 & 638 & 37.1 & 6.93 & 56.9 & 6.56 & 3.51 \\
\hline 3 & 56.5 & 82.3 & 628 & 26.3 & 7.46 & 56.0 & 6.42 & 2.91 \\
\hline 4 & 58.9 & 87.0 & 618 & 25.6 & 8.61 & 56.0 & 6.96 & 3.48 \\
\hline
\end{tabular}

The strengths of handsheets filled with hydroxypropyl starch (MS 0.090 ) were higher than handsheets filled with original starch. Table 5 and Figure 1 (b) show that $25.7 \%$ increase in the burst index and the increased porosity with addition of $2 \%$ hydroxypropyl starch (MS 0.090) compared to control. This experiment proved that the higher addition (more than 1-2\%) of hydroxypropyl starch only at high MS could improve strength of paper (but not al low MS).

Table 6. Physical properties of handsheets filled with hydroxypropyl starch, Molar of Substitution 0.125, in differet percentage.

\begin{tabular}{|c|c|c|c|c|c|c|c|c|}
\hline $\begin{array}{c}\text { Percen } \\
\text { t of } \\
\text { starch }\end{array}$ & $\begin{array}{c}\text { Gram } \\
\left(\mathrm{g} / \mathrm{m}^{2}\right)\end{array}$ & $\begin{array}{c}\text { Thick. } \\
(\mu \mathrm{m})\end{array}$ & $\begin{array}{c}\mathrm{AD} \\
\left(\mathrm{kg} / \mathrm{m}^{3}\right)\end{array}$ & $\begin{array}{c}\text { Porosity } \\
(\text { Gurley } \\
\text { second })\end{array}$ & $\begin{array}{c}\mathrm{DT} \\
(\mathrm{sec})\end{array}$ & $\begin{array}{c}\text { Tensile } \\
\text { Index } \\
(\mathrm{kN} . \mathrm{m} / \mathrm{kg})\end{array}$ & $\begin{array}{c}\text { Tear } \\
\text { Index } \\
(\mathrm{N} . \mathrm{m} / \mathrm{g})\end{array}$ & $\begin{array}{c}\text { Burst } \\
\text { Index } \\
(\mathrm{kPa} . \mathrm{m} / \mathrm{g})\end{array}$ \\
\hline 0 & 53.4 & 77.5 & 632 & 34.4 & 6.16 & 48.9 & 7.41 & 2.61 \\
\hline 1 & 59.7 & 89.3 & 599 & 15.8 & 6.59 & 47.7 & 7.89 & 2.97 \\
\hline 2 & 55.3 & 81.5 & 621 & 18.7 & 6.62 & 51.5 & 6.96 & 3.28 \\
\hline 3 & 54.2 & 79.3 & 626 & 27.4 & 7.96 & 52.9 & 6.69 & 3.34 \\
\hline 4 & 57.9 & 85.9 & 617 & 17.9 & 9.56 & 55.2 & 6.76 & 3.55 \\
\hline
\end{tabular}

Table 6 and Figure 2 (a) showed that the 19.1\% increased in the brust index and lower drainage time on 2\% addition of hydroxypropyl starch (MS 0.125) could be used to determine the optimal amounts of hydroxypropyl starch to be added at this level. The higher drainage time at $3-4 \%$ addition could be interpreted that hydroxypropyl starch might retained more than the lower addition levels. Anyhow, the strengths were not much improved if the hydroxypropyl starch was further added. When hydroxypropyl starch (MS 0.180) was added in the stock, the 11.7\% increased in the burst index at $1 \%$ addition and burst index were not much improved in other level of addition. Furthermore, the high porosity (34.9 Gurley second) could be used to monitor that hydroxypropyl starch added at $1-2 \%$ in the pulp slurry. 


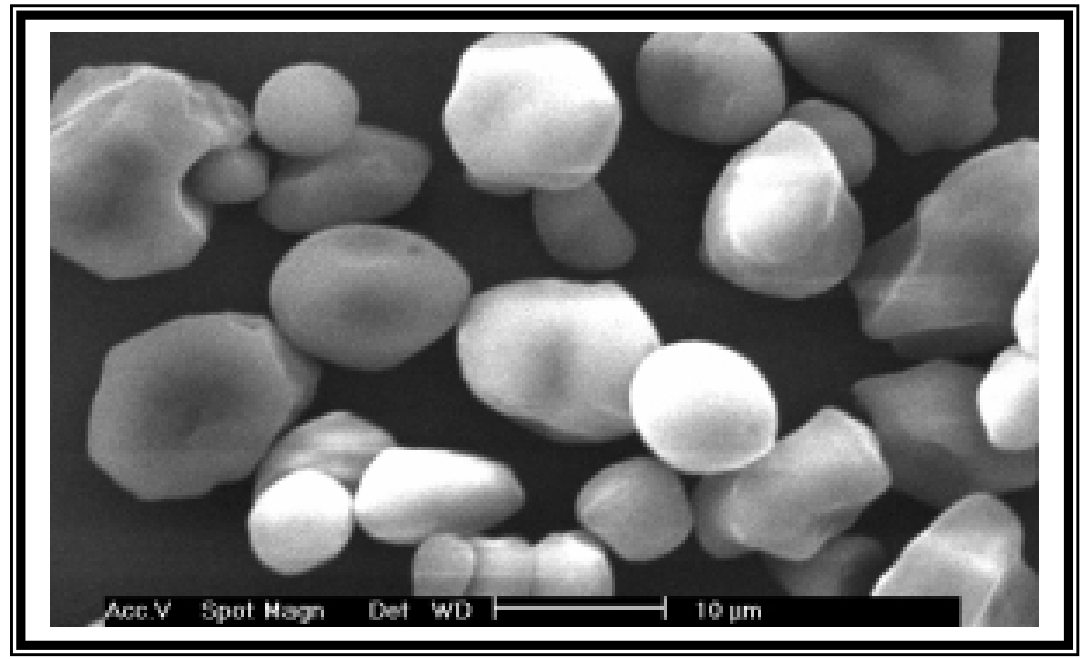

(a)

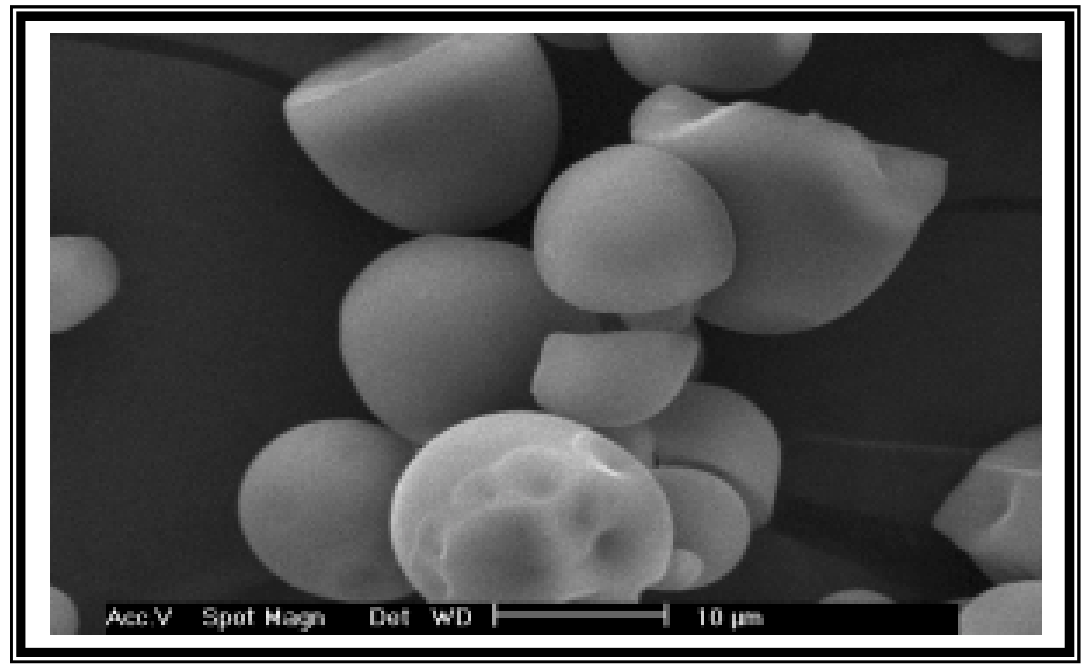

(b)

Figure 2. SEM of sorghum Zh-30 starch: (a) Hydroxypropyl (MS 0.125); (b) Hydroxypropyl (MS 0.180).

Table 7. Physical properties of handsheets filled with hydroxypropyl starch, Molar of Substitution 0.180, in differet percentage.

\begin{tabular}{|c|c|c|c|c|c|c|c|c|}
\hline $\begin{array}{c}\text { Percent } \\
\text { of } \\
\text { starch }\end{array}$ & $\begin{array}{c}\text { Gram } \\
\left(\mathrm{g} / \mathrm{m}^{2}\right)\end{array}$ & $\begin{array}{c}\text { Thick. } \\
(\mu \mathrm{m})\end{array}$ & $\begin{array}{c}\mathrm{AD} \\
\left(\mathrm{kg} / \mathrm{m}^{3}\right)\end{array}$ & $\begin{array}{c}\text { Porosity } \\
(\text { Gurley } \\
\text { second })\end{array}$ & $\begin{array}{c}\mathrm{DT} \\
(\mathrm{sec})\end{array}$ & $\begin{array}{c}\text { Tensile } \\
\text { Index } \\
(\mathrm{kN} . \mathrm{m} / \mathrm{kg})\end{array}$ & $\begin{array}{c}\text { Tear } \\
\text { Index } \\
(\mathrm{N} . \mathrm{m} / \mathrm{g})\end{array}$ & $\begin{array}{c}\text { Burst } \\
\text { Index } \\
(\mathrm{kPa} . \mathrm{m} / \mathrm{g})\end{array}$ \\
\hline 0 & 53.4 & 77.5 & 632 & 34.4 & 6.16 & 48.9 & 7.41 & 2.61 \\
\hline 1 & 57.9 & 88.1 & 589 & 34.9 & 8.44 & 52.4 & 7.88 & 2.92 \\
\hline 2 & 58.9 & 89.1 & 593 & 22.7 & 8.79 & 53.4 & 7.74 & 2.94 \\
\hline 3 & 49.5 & 73.7 & 607 & 24.8 & 7.79 & - & 6.56 & 2.81 \\
\hline 4 & 49.5 & 71.7 & 625 & 23.8 & 8.56 & - & 5.99 & 3.22 \\
\hline
\end{tabular}


All of physical properties (Table 5, 6 and 7) gave almost the same increase by increasing hydroxypropyl starch levels. Also, if high starch concentration (3\%) was used the burst index actually decreased. So at 1-2\% of any type of MS is recommended to be used in these conditions. However, in commercial point of view, the cheapest one should be used i.e. the hydroxypropyl starch at low MS.

\section{CONCLUSIONS}

Higher alkaline aqueous, reaction mixture used for preparation of hydroxypropyl starch of sorghum Zh-30 affected positively the level of MS, but using $\mathrm{NaOH}$ with molarity more than 0.395 and propylene oxide to produce the derivatives with the MS higher than 0.180 was considered ineffective. Depending on the MS, hydroxypropyl starch of sorghum Zh-30 had lower pasting temperature and maximum consistency temperature, but higher viscosity and stability of the starch pastes, as compared to the original starch. The low pasting temperature, high water holding capacity and low retrogradation susceptibility suggested that hydroxypropyl starch of sorghum Zh-30 starches could be suitable and potential to be used in paper industry.

Higher addition of hydroxypropyl starch did not increase the burst and tensile strengths of handsheet and tear strengths were prone to decrease. The results indicated that 1-2\% addition of hydroxypropyl starch were optimal for papermaking. When MS of hydroxypropyl starch was increased, the burst index of paper did not change much. Furthermore, when hydroxypropyl starch with high MS was added in higher percentages, the burst index tended to decrease.

\section{REFERENCES}

1. ICRISAT, Industrial Utilization of Sorghum. Proceedings of Symposium on the Current Status and Potential of Industrial Uses of Sorghum, 59p (1990).

2. MAHER, S.L. and CREMER, C.W., Use of modified starches: paper industry. In: Modified Starches : Properties and Uses. Ed. O.B. Wurzburg, M.S.. CRC Press, Inc. Boca Raton, Florida (1989).

3. KIM, H. R., HERMANSSON, A. M. and ERIKSSON, C.E., Structural characteristic of hydroxypropyl potato starch granules depending on their molar substitution. Starch/Starke. 44, 111-116 (1992).

4. RUTTENBERG, M. W. and SOLAREK, D., Starch derivatives: Productions and uses. In Starch: Chemistry and Technology. Ed. R. L. Whistler. J. N. BeMiller, and E. F. Paschall, pp. 311 - 388. Academic Press, Toranto (1984). 
5. AOAC, "Official methods for analysis. Association of Official Analysis", (1984).

6. Tappi Test and Methods, Tappi press (1996)

7. JOHNSON, D. P., Spectrophotometric determination of hydroxypropyl group. Analitical Chemistry, 41: 859 - 880 (1969). 